\title{
IMPROVING GEOGRAPHY PRE-SERVICE TEACHERS' UNDERSTANDING OF SATELITE IMAGERY ANALYSIS USING ER MAPPER SOFTWARE WITH A MODULE
}

\author{
Dede Sugandi ${ }^{1}$, Lili Somantri ${ }^{2}$ \\ Mapping Survey and Geographic Information, Universitas Pendidikan Indonesia, Bandung, \\ Indonesia
}

\author{
dedesugandi@upi.edu' ${ }^{1}$ lilisomantri@upi.edu²
}

First draft received: 03 May 2018 Accepted: 31 June 2018 Final proof received: 20 Aug 2018

\begin{abstract}
The development of student potential is influenced by how the teacher prepares the steps of the learning process. This means that teacher's preparation and planning for the learning process determines the achievement of learning objectives. There is an indication that students have low mastery in the skills of imagery analysis on the topic of remote sensing. This research aims to find ways to assist students in the learning process of remote sensing and find about the appropriateness of the form of learning process to the learning materials as well as the allocated time and the steps in the learning process. More specifically, it aims to assist students in gaining understanding and ability of image data analysis using Er Mapper software. The population consisted of 195 students, while the sample taught to improve their understanding of the steps taken in imagery analysis only included 90 students. The students were divided into two groups, the control class and the experimental class, with 45 students respectively. In assessing students' understanding, this research was aided by four testers who assessed and determined the time taken for students to complete each stage of imagery analysis, with the criteria of: 1) 0-1 (very fast), 2)>1-2 (fast), 3)> 2-3 (slow), and 4)> 3-4 (very slow). The scores of the imagery analysis of the control class and experimental class students were 3.30 (very good) and 3.38 (very good), respectively, with a difference of 0.08 . The difference in the understanding and ability was more strongly indicated by the speed or time taken to complete the analysis stages for each meeting. The control class' average speed was 3.51 (very slow), while the experimental class was 1.44 (fast). To accelerate the learning process of image analysis, the lab work should be assisted with guidebooks or modules in each meeting. With the module, students can learn independently.
\end{abstract}

Keywords: Image analysis, Er Mapper, learning process, meeting time, module

To cite this paper (in APA style):

Sugandi, D., \& Somantri, L. (2018). Improving geography pre-service teachers' understanding of satellite imagery analysis using Er mapper software with a module. International Journal of Education, 11(1), 59-67. doi: http://dx.doi.org/10.17509/ije.v11i1.10902

\section{INTRODUCTION}

School is an educational institution to develop the potentials of students and prepare them to enter the society. The progress and development of students is influenced by the creativity of teacher's training and education institutes in helping pre-service teachers understand the materials to teach easily. Greenberg, McKee. \& Walsh (2013) reported that schools of education are coming under increasing scrutiny for how effectively they prepare teachers. Classroom learning process largely requires students to memorize various pieces of information, in which their brains are forced to memorize and hoard information (Kristanto, 2015). On the other hand, teachers are required to have the ability to develop student potential. Therefore, to develop professional teachers, pre-service teachers need to be equipped with important competences. The competences include leadership in the classroom and the ability to develop learning methods. Nor, Rahman, Nor, Talha, and Zabidi (2016) explained that instructional leadership is about actions carried out by school leaders as a headmaster or school principal to improve the quality of teachers' instruction and improve students' learning outcomes. Improving the quality of student learning outcomes is strongly influenced by the success in the learning process associated with the involvement, understanding, and appreciation of learning on the material being studied (Merta; 2013). 
Hence, the learning outcomes expected from preservice teachers entail the competence to face various challenges in life. This is so because the rapid change and increased complexity of today's world present new challenges and new demands on educational system. According to Alshurfat (2016), education and the quality of its provision are a means to secure advantage in the global market. Anne and Hiebert (2017) added that past difficulties in finding relationships between content preparation and teaching competencies have been due, in part, to an absence of specific hypotheses about the nature of content knowledge studied and its use several years later, in teaching-like contexts.

The essence of the previous discussion is that teachers should endeavor to find the appropriate learning methods because students' ability in understanding the world can be reflected in how they understand the learning materials. Besides learning methods, learning media will help students understand learning materials and master the technology information. Diez's study (2010) explored the relationship between teacher preparation and teaching competence, focusing on one piece of a much larger puzzle of the relationships between teacher preparation and the quality of classroom teaching. For the effectiveness and efficiency of teaching and learning process, the use of media in teaching certainly helps teachers in delivering the materials and assists students in understanding the materials well (Nurmadiah, 2016). Thus, learning media play a very important role to make students, as the receivers of the messages, understand the messages or learning materials (Dahlia, 2017). Halili, Sulaiman, and Rashid, (2011) suggested improving the use of technology, especially the media of video conferencing, in order to give good impressions and make the learning process more efficient. In essence, learning process must be aided by learning media that serve to assist students in learning.

The role of teachers in preparing the materials for classroom teaching and learning is very important in order to make the learning materials easily understood by students. This standard competence of teachers is developed holistically from the four main competencies (pedagogic, personality, social, and professional) and the four competencies are integrated in teacher performance (Kasmuri, Tirta, \& Dewi, 2014). Teachers should master the scientific substance related to their fields of study; understand the teaching materials included in the school curriculum; and understand the structure, concepts, and methods of science that subsume or are coherent with the teaching materials. They should also develop professionalism in a sustainable manner by doing reflection and utilizing information and communication technology for selfdevelopment (Novauli, 2015). According to Asmarani, (2014), the rapid development of the times and globalization demands an increase in the quality of education. Each education system must be able to make changes towards improvement and better quality. It means that in the learning process, teachers must have the competence of the materials taught to them to meet the desired goals of the learning process.
Competent teachers will be able to boost students' confidence in meeting the learning goals.

Thus, teacher development must be ongoing because the fundamental principle is that a teacher must be a learning person, who continues learning throughout his or her lifetime. As professional teachers who also have obtained the teacher's certificate, teachers are indeed obliged to maintain their professionalism (Mahpudz, 2014). Teacher development aims to improve teacher competence in accordance with learning goals. Mastery goals predicted performance only when these goals were presented as socially useful but not presented as socially desirable, especially among low achievers, those who need mastery goals the most to succeed (Dompnier, Darnon, \& Butera, 2015). Although learning process may also be influenced by other factors, still teachers should continuously endeavor to assist students in their learning process and in understanding the teaching materials. Increasing students' understanding of teaching materials can be facilitated with media and modules. According to Syaf'ii and Yasin (2013), the increase in the quality of learning is made possible through learning innovation using learning modules. The planned and organized implementation of a module by teachers will not only improve students' thinking skills, but also increase the quality of science and technology, consistent with the aim of Indonesian education. In addition, learning process is closely related to curriculum, methods, stages, materials, and media. The development of science and technology also has an impact on learning process, especially in relation to students' preparedness, speed, and ability in understanding learning materials.

The results of observation of the teaching and learning process in the topic of remote sensing reveal that pre-service teachers have a lack of mastery of remote sensing analysis skills so that they cannot optimally follow the teaching and learning process. Another problem is the insufficient allocated time in the classroom, thereby requiring students to learn autonomously. In the teaching and learning of remote sensing, the pre-service teachers are not only required to understand the materials of imagery analysis, but also to be able to practice the analysis. On the one hand, they are required to master the software needed in learning the materials of remote sensing, but on the other hand the materials are really new for them. As a result, a relatively long time for learning is needed; meanwhile, the curriculum allocates limited time for students to digest the knowledge and acquire the skills.

Remote sensing is a technique for analyzing land covers on the surface of the Earth. This technique deals with how to turn the recording results into useful information. According to Lillesand and Kiefer (2007), remote sensing is the science and art of obtaining information about an object, region, or phenomenon through the analysis of data obtained by using a tool without any direct contact with the object or phenomenon being studied. The results of satellite recording are still in the forms of images; therefore, they 
need to be rendered into useful information that can be used for various institutions. These users include Ministry of Forestry, Ministry of Environment, Ministry of Agriculture, BBSDLP (Indonesian Center for Agricultural Land Resources Research and Development), Irrigation Agency-Ministry of Public Work, Coordinating Ministry, BPS (Central Bureau of Statistics), Bappenas (National Development Planning Agency), Bulog (Indonesian Bureau of Logistics), and KKP (Ministry of Marine Affairs and Fishery). The maps required by the agencies/institutions are obtained from remote sensing imagery, such as maps of forest covers, agricultural areas, water resources, and information about forest types, agricultural production, and lake potentials for cultivation (Kushardono, et al., 2014).

The topic of remote sensing is related to technical knowledge, understanding, and skills; meanwhile, preservice geography teachers are mostly unfamiliar with technical knowledge and skills. Remote sensing is also a topic that requires the mastery of software use and language. This lack of mastery becomes a constraint for teachers in implementing the learning process. As a result, the learning outcomes of pre-service geography teachers in the topic of remote sensing are less than satisfactory. Furthermore, the broad coverage of the remote sensing materials is to be completed within a quite limited allocated time of around 14 meetings (14 $\mathrm{x}$ 4 hours), which include 5 theoretical meetings and 9 practicum meetings. The incompatibility between the breadth of the remote sensing learning materials and the allocated time is compounded by language difficulty. Er Mapper software uses English, while pre-service teachers do not have good proficiency in English. Therefore it is necessary to have a model of learning to facilitate mastery of software and learning materials.

To render image data into useful information, software is needed. There has been some research on developing software with various platforms that can help students better understand and apply the knowledge of remote sensing imagery. Sato \& Yokoyama (2008) created spreadsheet using Microsoft Excel to assist students in analyzing and interpreting remote sensing imageries and map images. Sohrabinia, Sadeghian, and Manavi (2008) developed an application for image processing and analysis for large scale map revision. There is also research by Voigt, Kemper, Ridlinger, Kiefl, Scholte, and Mehl (2017) on the analysis of satellite image for disaster and crisis management support. However, none of the research focused on preservice Geography teachers. Therefore, this research focused on improving pre-service teachers' understanding of satellite imagery using Er Mapper assisted with a module created by the researchers. The module will play a key role in helping the pre-service teachers. The teaching and learning of remote sensing requires ample time to make pre-service geography teachers easily understand and apply it. Once they gain good understanding and acquire the skills, these preservice teachers will be able to teach the learning materials to their future students. The questions then are: How can lecturers help pre-service teachers learn about remote sensing easily? What steps should the lecturers take in the teaching and learning process of remote sensing to pre-service teachers? The answer to the question is expected to help the learning process of remote sensing, which is considered difficult, becomes easy to understand and easily applicable.

Herein, the present research aims to develop a learning model for remote sensing learning materials appropriate to the time specified in the Geography Education curriculum. The learning model is expected to be applicable to develop the knowledge, understanding, and skills of pre-service geography teachers. With the knowledge, understanding, and skills, the pre-service teachers will be able to develop their own learning process once they become professional teachers.

\section{METHOD}

This research focuses on geography pre-service teachers' understanding and ability in image data analysis through the use of $\mathrm{Er}$ mapper created by the researchers. The ability will be achieved if students understand the instructions of Er Mapper and the steps and stages of analysis. The learning process was divided into 2 groups: 1) A group of students who were taught with direct learning in the classroom with instructions from the lecturer, and 2) A group of students who analyzed the image data by referencing the guideline made by the lecturer in the form of a module. Descriptive method was employed to analyze the data collected in this research to answer the research questions.

The population of the research consisted of the first semester (2017/2018 academic year) and third semester (2016/2017) pre-service teachers of the Department of Geography Education. In total, there were 195 pre-service teachers. The selected sample consisted of 90 male and female pre-service teachers who were in their third semester (2016/2017 academic year).

To assess the acquired ability and skills of the preservice teachers, the following things were carried out: First, assessment scale of imagery analysis for the first group (control class). The scale was developed to find the speed or the time required by students to complete every stage of imagery analysis. A survey was done to obtain this information and how the students applied the stages of analyzing remote sensing imagery. Second, assessment scale of imagery analysis for the second group (experimental class): In the second group, this scale was developed to determine the speed or the time required by students to complete every stage of imagery analysis by using the guidance made by the lecturers. A survey was conducted to determine the time required in image analysis and how the students applied the guideline of remote sensing image analysis made by the lecturers.

To assess the learning process, specifically how fast the students understand how to analyze remote sensing imagery and gain the skills in imagery analysis, as indicated by the speed in completing every imagery analysis stage, the researchers were assisted by four testers. They have understanding and skills in imagery analysis. These testers assessed the speed of analysis 
and the skills acquired by the pre-service teachers and the level of errors made by the pre-service teachers. The speed of analyzing the image is classified as: a) 0 1 (very fast), b)> 1-2 (fast), c) > 2-3 (slow), and d) $>3-4$ (very slow). In this assessment, two steps were taken, namely:

First, testers made sure they shared similar perceptions and scoring points for pre-service teachers in each step of image data analysis, and the testers classified the scores into: a) 0-1 (very fast), b)> 1-2 (fast), c) > 2-3 (slow), and d) > 3-4 (very slow).

Second, the testers assessed the learning process of imagery analysis by classifying the scores into four categories. The assessment results from the four testers were averaged for the group of pre-service teachers without using the guidance module and the group of pre-service teachers using the guidance module.

\section{RESULTS AND DISCUSSION Descriptive Analysis}

Analysis of Landsat 8 imagery conducted in the learning process is part of the curriculum and compulsory courses for pre-service teachers of Geography Education Study Program. The imagery analysis uses Er Mapper Volume 6.4. The pre-service teachers were divided into two groups based on the types of learning process, namely: a group without the use of a guidance module (hereinafter referred to as control class) and a group using a guidance module (hereinafter called experimental class). In the learning process, the lecturers provided instructions to help the pre-service teachers understand and able to perform imagery analysis; therefore, the analysis stages were divided into nine meetings. At each meeting, the lecturers provided directions and students could perform the analysis by themselves.

In the meantime, testers synchronized their perceptions of the classification of time taken to analyze image data: a) 0-1 (very fast), b)> 1-2 (fast), c)> 2-3 (slow), and $d)>3-4$ (very slow). The classification of these scores is based on the learning process for every stage or meeting.

\section{Assessment of Speed in Understanding (Completing) Imagery Analysis Stages Meeting 1: Image Geometric Correction (IGC)}

In the image data analysis exercise, the content of the learning process is focused on geomorphological analysis. The stages performed in the analysis begin with a Log In to Er Mapper application, and the menu display and other tools will appear.

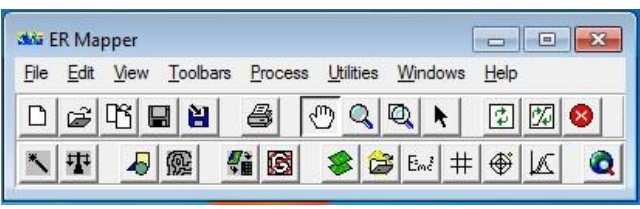

Figure 1. Menu display

The instructions go as follow: one the menu bar, select Process >> and Geocoding Wizard Sub-Menu. After that, Geocoding Wizard tab will appear and the first step is to select Polynomial (for satellite imagery) >> Input image through the icon of Load Algorithm or Dataset. While inputting the image, the Geocoding Wizard tab will appear to input Dataset or Algorithm $>$ and then, select Volume to search for storage of Satellite Imagery on your PC or Laptop >> next, select Satellite Image(s) to be corrected.

Next, on the Geocoding Wizard tab, select Polynomial Setup >> select Cubic. On the Geocoding Wizard tab, select GCP Setup, and input the corrected satellite imagery into Geocoded imagery, vectors, or algorithm by selecting Load Corrected Algorithm or Dataset. Subsequently, on the Geocoding Wizard tab, select GCP Edit, and some new tabs containing satellite imagery will appear. Close the Satellite Imagery tab called CORRECTED GCP ZOOM and UNCORRECTED GCP ZOOM and delete all GCP data on the Geocoding Tab Wizard and add some GCP data into the Geocoding Wizard Tab.

Table 1. Time and Score for IGC

\begin{tabular}{lcc}
\hline & Control & Experimental \\
\hline Average Score & 3.42 & 3.37 \\
\hline Average Time & 3.60 & 1.40 \\
\hline Classification & 4 (Very slow) & 2 (Fast) \\
\hline
\end{tabular}

\section{Meeting 2: Selection of Red, Green, Blue (RGB)}

The instructions for stage 2 are as follows: Change the Band on each Satellite Imagery tab using Edit Algorithm on Er Mapper tab.

Select Edit Algorithm, and then Algorithm >> Arrange tab will appear, change it into $R-G$ - B by using the pointer.
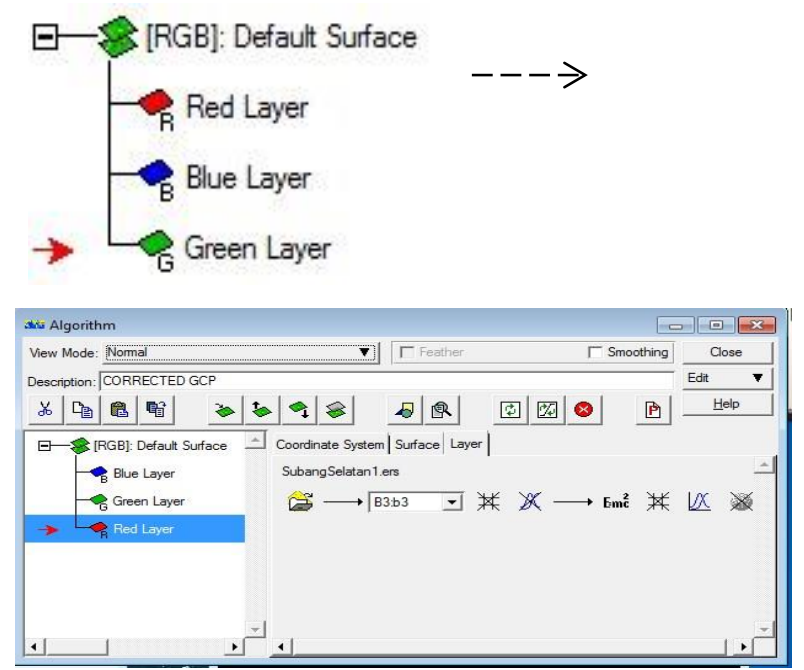

Layers $\overline{R-G}-\mathrm{B}$ will appear, then change the bands according to the following composition: 


$\begin{array}{lll}\text { - } & \text { Red Layer } & \text { : B4: Band } 4 \\ \text { - } & \text { Green Layer } & \text { : B5: Band } 5 \\ \text { - } & \text { Blue Layer } & \text { : B6: Band } 6\end{array}$

Apply the layers to UNCORRECTED GCP and CORRECTED GCP tabs and the hues of the satellite imagery will automatically change. After changing the second Band of the satellite imagery, enter the geographic coordinate points by clicking on similar displays; for example, by marking the intersections found on both images. To make it easy to tag, use the Zoom Box Tool to zoom in on the image.

To add a point in another location, click "add new GCP" on the geocoding wizard display. Add 9 points to make a total of 10 points. The smaller the RMS number, the more precise the coordinates will be. Next, select Rectify on the Geocoding Wizard tab to save by selecting Save File and Start Rectification and ticking the box on display rectification image and the command will appear $\gg$ Select Yes. Er Mapper will process the corrected imagery results and the Info Tab will appear to notify that that the process has been completed. Additional steps to see whether corrected satellite images are correct or not are: Select Menu Bar >> View $>>$ Cell Coordinate. By placing the pointer on the image, the coordinates will appear.

Table 2. Time and Score for RGB

\begin{tabular}{lcc}
\hline & Control & Experimental \\
\hline $\begin{array}{l}\text { Average } \\
\text { Score }\end{array}$ & 3.40 & 3.32 \\
\hline Average Time & 3.40 & 1.40 \\
\hline Classification & 4 (Very Slow) & 2 (Fast) \\
\hline
\end{tabular}

Meeting 3: Cropping (Crop)

Image cropping is done to narrow the area to be analyzed. It is done through the following processes:

1. First, open $\mathrm{Er}$ Mapper and the initial view of $\mathrm{Er}$ Mapper will pop up, and then open the data to be cropped and click OK, the image data will appear in the form of area image.

2. Making algorithm for data analysis is done by clicking the icon $\&$. Data analysis in the form of algorithm covers image sharpening, filtering, making formula, creating composite images, etc. For geomorphological analysis, use Bands 4,5 , and 7 . On the Red layer, choose band 4 . On the Green layer, choose band 5 , and on the Blue layer, choose band 7. To brighten the display, click and zoom

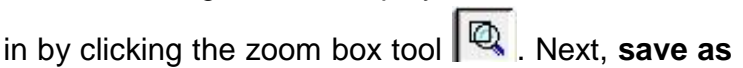
by clicking 빙. Save into "alg" file format and click OK.
Table 3. Time and Score for Cropping

\begin{tabular}{lcc}
\hline & Control & Experimental \\
\hline Average Score & 3.39 & 3.32 \\
\hline Average Time & 3.60 & 1.40 \\
\hline Class & 4 (Very Slow) & 2 (Fast) \\
\hline
\end{tabular}

Meeting 4: Unsupervised (Unsup)

Unsupervised method is one of the classification methods, where the computer automatically calculates and recognizes spectral values. This classification is to determine which classes are created. The stages in this classification are as follows:

1. Create a cropped image by clicking format.

2. Click process and select calculate statistics, which serves to calculate the statistical value of a dataset. Tick Force recalculate stats box and select OK. Wait until the calculate statistics is completed, and then click OK and close the calculate statistic tab.

3. Click classification and click ISOCLASS Unsupervised to perform the classification. A window display will appear. Fill the display with the cropped image in "ers" format. On the Input Dataset and Output Dataset menu, click but on the Output Dataset tab, the name will be slightly changed by the Input Dataset; for example, there will be an addition of the word "isso". On the maximum number of classes, change the number into 20.

4. Next, the processing status will appear, followed by "processing status successfully". Then, click OK.

5. Click the algorithm with the icon $\&$ and select Unsupervised file by clicking and the image with blue color will subsequently appear. On the algorithm box, change Default Surface from Pseudeo into class Display by right-clicking the mouse, so that the image will change into black and white.

Table 4. Unsupervised Time and Score

\begin{tabular}{lcc}
\hline & Control & Experimental \\
\hline Average Score & 3.39 & 3.44 \\
\hline Average Time & 3.60 & 1.00 \\
\hline Classification & 4 (Very slow) & 1 (Very fast) \\
\hline
\end{tabular}

\section{Meeting 5: Coloring (Col)}

The cropped images can be changed in terms of colors and class names as desired. On the Edit menu, select Edit Class/Region Color and Name, and color selection display will pop up. Enter the dataset by clicking 
OK. Next, select autogen and tick the full saturation box. Then, click autogen. This will change the color on the edit box region. To make it easier to interpret the data, click View and select Cell Values Profile that will display Digital Number (DN) pixels previously selected on each band. To make image identification easier, click the Zoom Tool Box $\sqrt{6}$; afterwards, using the pointer tool with the icon select the area to identify by clicking it. Next, on Cell Values Profile, the number of the previously clicked regions will appear.

Subsequently, change the class name of the region previously unlabelled according to the number shown on the Cell Value Profile. Then, save directly in the Edit Region, and select Save as icon 님 and then create a new file with "ers" and "alg" formats and close it.

Table 5. Coloring Time and Score

\begin{tabular}{lcc}
\hline & Control & Experimental \\
\hline Average Score & 3.33 & 3.36 \\
\hline Average Time & 3.60 & 1.60 \\
\hline Class & 4 (Very Slow) & 1 (Fast) \\
\hline
\end{tabular}

\section{Meeting 6: Supervised (Super)}

The sixth meeting discusses supervised classification.

The stages of supervised classification include:

1. Open the combined file for geomorphological analysis.

2. Digitize the file by clicking Edit>Edit/Create Region, then click OK. The digitizing tab will pop up on the display 盟 to annotate each region. Label each digitized region with its geomorphological name, such as;

Fluvial>Apply>save 맴, Karst>Apply>save 묨, and so on. The results will look like the following figure.

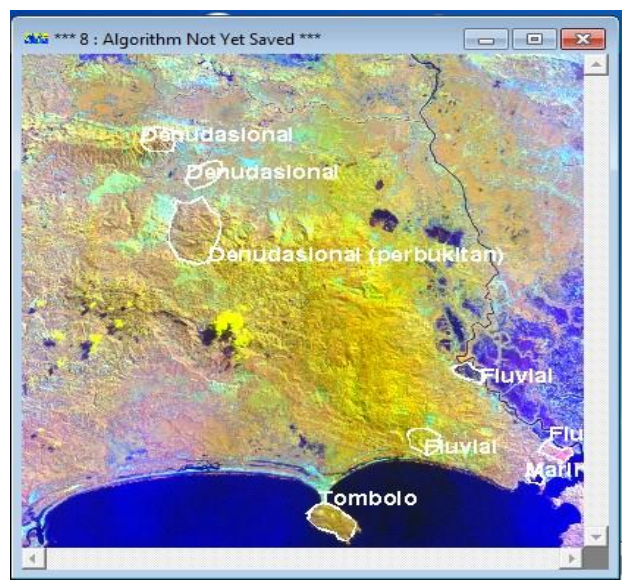

Figure 2. Satellite Image
Table 6. Supervised Time and Score

\begin{tabular}{lcc}
\hline & Control & Experimental \\
\hline $\begin{array}{l}\text { Average } \\
\text { Score }\end{array}$ & 3.10 & 3.39 \\
\hline Average Time & 3.40 & 1.60 \\
\hline Classification & 4 (Very Slow) & 2 (Fast) \\
\hline
\end{tabular}

Meeting 7: Calculation Process (CP)

In this meeting, a calculation process takes place as follows:

1. Click Process $>$ Calculate Statistic. Tick on the Force recalculate stats, and then click Ok. After that "successfully" icon will appear, and then click >close.

2. Next, carry out the classification process by clicking Process $>$ Classification $>$ Supervised Classification and click Ok.

3. Open the classified file by clicking Window $>$ New Window.

4. Next, open the classified file by clicking Ok. Then click Edit> Edit Class/Region Color and Name. This step adjusts the geomorphological shape to the desired color.

5. Enter the classified file, and then click Auto-gen colors, tick Full Saturation box and click Ok. The display will change and click Save.

Table 7. Calculation Process Time and Score

\begin{tabular}{lcc}
\hline & Control & Experimental \\
\hline $\begin{array}{l}\text { Average } \\
\text { Score }\end{array}$ & 3.11 & 3.34 \\
\hline Average Time & 3.40 & 1.60 \\
\hline Classification & 4 (Very Slot) & 1 (Fast) \\
\hline
\end{tabular}

Meeting 8: Creating Region (CR)

In the subsequent meeting, the stages of creating region are implemented, which include:

1. Click Edit>Edit/Create Regions, and then click $\mathbf{M}$ .On the Map Object Select, click Algorithm at the Category tab to enter Logo.

2. On the Algorithm Name, drag the figure and insert it into the image that will be in layout. Open the logo

file to be inserted with "alg" format by clicking and remove the checklist from the Fast Preview to display the logo of UPI. Next, to make an ideal size of the logo, click

3. To add a grid, on the Map Object Select, click grid.

4. Next, drag the third grid written with "LL" to the image to be in layout.

5. Arrange the Map Object Attribute to create the desired display.

6. To create the text under the logo, click Title on the Map Object Select section, Wind Direction by selecting North_Arrow on the Map Object Select, Scale, and Legend_Item on Map Object Select. 
7. Enter the source by clicking Title on the Map Object Select, and apply the previous stages of creating titles and posts.

8. Next, save one by one, starting from legend, grid, tittle, and so on, and save by clicking Save as.

Table 8. Creating Region Time and Scores

\begin{tabular}{lcc} 
& Control & Experimental \\
\hline Average Score & 3.29 & 3.33 \\
\hline Average Time & 3.80 & 1.40 \\
\hline Class & 4 (Very Slow) & 2 (Fast) \\
\hline
\end{tabular}

Meeting 9: Layout (LO)

The results of image analysis can be printed by taking the following steps:

1. Click algorithm and open the file in the issoclas by clicking

2. Right click on the Pseudeo Layer > click Class Display.

3. Next, click Edit>Add Vector Layer>Annotation/Map Composition.
4. Click Page Setup, and the following display will pop up on the screen. Change the background color into white, change the Constraint menu into Auto Vary: Border, and adjust the paper and the scale to fit the desired result.

Table 9. Layout Time and Score

\begin{tabular}{lcc} 
& Control & Experimental \\
\hline $\begin{array}{l}\text { Average } \\
\text { Score }\end{array}$ & 3.37 & 3.48 \\
\hline Average Time & 3.40 & 1.60 \\
\hline Class & 4 (Very Slow) & 2 (Fast) \\
\hline
\end{tabular}

From the assessment carried out by the four testers of the understanding of Landsat imagery analysis, indicated by the speed in applying the analysis stages, it can be seen that the speeds of completing the analysis stages were different between the control and experimental groups. In the control group, the lecturer only gave directions about the steps to be taken in the analysis, while in the experimental class the lecturer provided directions as also given in the module owned by students.

Table 10. Comparison of Scores and Times for Each Meeting

\begin{tabular}{lcccccccccc}
\hline & \multicolumn{1}{c}{ Meeting numbers } \\
\hline & 1 & 2 & 3 & 4 & 5 & 6 & 7 & 8 & 9 \\
\hline Control Class Score & 3.42 & 3.40 & 3.39 & 3.29 & 3.33 & 3.10 & 3.11 & 3.29 & 3.37 \\
\hline $\begin{array}{l}\text { Experimental Class } \\
\text { Score }\end{array}$ & 3.37 & 3.32 & 3.36 & 3.44 & 3.36 & 3.39 & 3.34 & 3.33 & 3.48 \\
\hline Control Class Time & 3.60 & 3.40 & 3.60 & 3.60 & 3.60 & 3.40 & 3.40 & 3.80 & 3.40 \\
\hline $\begin{array}{l}\text { Experimental Class } \\
\text { Time }\end{array}$ & 1.40 & 1.40 & 1.40 & 1.00 & 1.60 & 1.60 & 1.60 & 1.40 & 1.60 \\
& & & & &
\end{tabular}

Table 10 illustrates that the scores of the students in the control class and that of the students in the experimental class were almost the same, namely 3.30 (good) and 3.38 (good), respectively, with a difference of 0.08 . However, differences can be observed in the time taken to complete the analysis stages in each meeting. The control class needed an average time of 3.51 (very slow) to complete the stages, which is much slower compared to the average time of the experimental class of 1.44 (fast). The differences between the control and experimental class analysis time for each meeting are shown in graph 1.

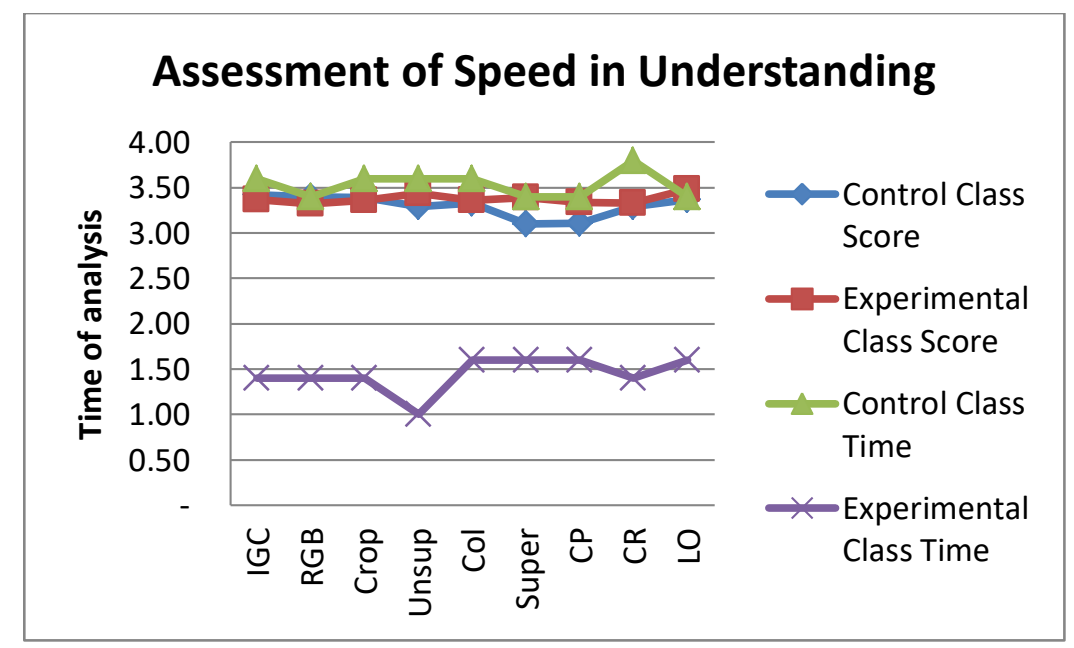

Figure 1. Differences in score and time between the control and experimental classes 
Based on the time needed for the experimental class students to complete the analysis, the level of understanding of the experimental class can be said to be better than that of the control class, because the experimental class was assisted by a guide. The guideline in the form of a module was always made the basis for analysis in each meeting, so that students did not have to ask the lecturers, saving them a lot of time to focus on practicing the analysis. On the other hand, in the control class, students who did not understand or forgot about a material needed to ask the lecturers. The time required to ask questions impacts on the speed of understanding in the analysis. This means that to improve the speed of understanding of students' analysis, they need to be assisted with a module.

With this module, students will follow the learning process step by step, so that the time required to study the image analysis is long enough, about 14 meetings and each meeting is $4 \times 50$ minutes (4 SKS). To master the study material of image analysis is by addition of lecture 3-4 times of class meeting. To conduct learning process that is compatible with the specified time, the lecturer arranged a step by step learning process about 9 times of class meeting. The rest of 5 class meeting is used to provide material in theoretically. it means that learning process will be effective if assisted with the guide book of image analysis steps from class meeting; 1) Image Geometric Correction, 2) Selection of Red, Green, Blue, 3) Cropping, 4) Unsupervised, 5) Coloring, 6) Supervised, 7) Calculation Process, 8) Creating Region and 9) Layout (LO).

The research has shown that pre-service teachers' understanding of satellite imagery analysis can be helped with the use of Er Mapper software, which is in line with the findings of Sato \& Yokoyama (2008); Sohrabinia, Sadeghian, and Manavi (2008); and Voigt, Kemper, Ridlinger, Kiefl, Scholte, and Mehl (2017). The use of a module in the teaching and learning has also greatly facilitate the pre-service teachers' autonomy, as is also confirmed by Nashiroh, Kamdi, and Elmunsyah (2017).

\section{CONCLUSION}

Remote sensing is a course that is characterized by high accuracy. The course materials should be understood and mastered by pre-service geography teachers who mostly do not really master the language used by Er Mapper Software and how to operate the software. Therefore, the learning process of remote sensing analysis should be assisted with a guidance or module for each meeting.

In addition, the learning process of image analysis is quite hard for students, so this learning takes a relatively long time. The time allotted for students to understand imagery analysis in the course is 14 meetings. To accelerate the understanding of the materials in this course, a module has been made, so as to adjust the ability to understand the materials to the allocated meeting times.

Finally, to speed up the time required in understanding imagery analysis, the course is divided into 5 meetings for theoretical learning and 9 meetings for practicing imagery analysis in accordance with requirements of the curriculum.

The use of the module can help improve the understanding of pre-service teachers in analyzing satellite imagery and increase their learning autonomy.

\section{REFERENCES}

Alshurfat, SS. (2016). Teachers application of the national professional standards in three northern jordanian provincial schools. International Journal of Education, 8(1), 59-77.

Anne K., \& Hiebert M.J, (2017). Effects of teacher preparation courses: Do graduates use what they learned to plan mathematics lessons?. American Educational Research Journal, 54(3), 524-567.

Asmarani, N. (2014). Peningkatan kompetensi profesional guru di sekolah dasar. Jurnal Administrasi Pendidikan, 2(1), $503-831$.

Dahlia. (2017). Pengaruh model pembelajaran kooperatif tipe circ (Cooperative Integrated Reading And Composition) dan berpikir kritis terhadap belajar menulis argumentasi. Jurnal Kajian Pendidikan dan Pengajaran, 3(2), 178187.

Diez, M.E. (2010). It is complicated: Unpacking the flow of teacher education's impact on student learning. Journal of Teacher Education, 61, 441-450.

Dompnier, B., Darnon, C. \& Butera, F. (2009). Faking the desire to learn: A clarification of the link between mastery goals and academic achievement. Psychological Science, 20, 939943. doi:10.1111/j.1467-9280.2009.02384.x

Greenberg, J., McKee, A. \& Walsh, K. (2013). Teacher prep review: A review of the nation's teacher preparation programs. Washington, DC: National Council on Teacher Quality. Retrieved from http://www.nctq.org/teacherPrep.

Halili, S. H., Sulaiman, S., \& Rashid, M. R. A. (2011). Keberkesanan proses pembelajaran menggunakan teknologi sidang video (the effectiveness of learning process using video conferencing technology). Jurnal Pendidikan Malaysia, 36(1), 55-65.

Kasmuri., Tirta, IM. \& Dewi, YS. (2014). Analisis pengaruh kompetensi tenaga guru dan kompetensi kepala sekolah terhadap capaian standar nasional pendidikan. Prosiding Seminar Nasional Matematika, Universitas Jember, 63-72.

Kristanto, Y.E. (2015). Pengaruh pembelajaran inquiri terbimbing terhadap kemampuan berpikir kritis dan hasil belajar IPA siswa kelas VII SMP. Jurnal Pendidikan dan Pembelajaran, 22(2), 197-208. 
Kushardono, D., Budhiman, S., Trisakti, B., Suwarsono, Maryanto, A., Widipaminto, A., Khomarudin, M.R. \& Winanto. (2014). Menentukan spesifikasi sensor satelit penginderaan jauh nasional berdasarkan informasi kebutuhan pengguna: Akusisi dan koreksi data penginderaan jauh. Proceedings of Seminar Nasional Penginderaan Jauh. Pusat Pemanfaatan Penginderaan Jauh LAPAN.

Lillesand, T. M. \& Kiefer, R. W. (2007). Penginderaan Jauh dan Interpretasi Citra. Trans. by Dulbahri. Gadjah Mada University Press: Yogyakarta.

Mahpudz, A. (2014). Policy Analysis Improvement Of Competence And Professionalism Of Teachers In Order To Improve The Quality Of The Organization Of Education In The District Sigi Central Sulawesi Province. Jurnal Penelitian Kebijakan Pendidikan, Vol. 7 (1), pp. 1-18.

Merta, L. M. (2013). Pengaruh Model Pembelajaran Kontekstual Terhadap Penguasaan Konsep Koloid Dan Sikap IImiah Siswa. Jurnal Pendidikan dan Pengajaran, Vol. 46(1), pp. 919

Nashiroh, P. K., Kamdi, W., \& Elmunsyah, H. (2017). The effectiveness of web-programming module based on scientific approach to train logical thinking ability for students in vocational high school. AIP Conference Proceedings, 1887. doi: 10.1063/1.5003551.

Nor, MM., Rahman, MNA., Nor NM., Talha, MN \& Zabidi AR (2016). Amalan kepimpinan pengajaran untuk penambahbaikan sekolah: Retrospeksi guru besar sekolah berprestasi tinggi. Jurnal Kepimpinan Pendidikan, 3(3), 44-53.

Novauli, M.F. (2015). Kompetensi guru dalam peningkatan prestasi belajar pada smp negeri dalam Kota Banda Aceh. Jurnal Administrasi Pendidikan, 3(1), 45-67.

Nurmadiah. (2016). Media pendidikan. Jurnal Al-Afkar, 5(1), 44-62.

Sato, K., \& Yokoyama, R. (2008). Spreadsheet education material using remote sensing image and map image. Proceedings of the International Archives of the Photogrammetry, Remote Sensing and Spatial Information Sciences, 37(B6a), 179-184.

Sohrabinia, M., Sadeghian, S., \& Manavi, D. (2008). Application of image processing and image analysis methods for large scale map revision. Proceedings of the International Archives of the Photogrammetry, Remote Sensing and Spatial Information Sciences, 37(B4), 13511354.

Syaf'ii, W. \& Yasin, RM. (2013). Problem Solving Skills and Learning Achievements through Problem-
Based Module in teaching and learning Biology in High School. Asian Social Science Journal, 9(12), 220-228.

Voigt, S., Kemper, T., Riedlinger, T., Kiefl, R., Scholte, K., \& Mehl. (2007). Satellite image analysis for disaster and crisis-management support. IEEE Transactions on Geoscience and Remote Sensing, 45(6), 1520-1527. 